\title{
DYMORFICZNY WYMIAR UWARUNKOWAŃ AGRESJI I PRZEMOCY DOMOWEJ - PRZEGLĄD WYBRANYCH ASPEKTÓW I EKSPLORACJI
}

Tekst dotyczy uwarunkowań agresji i przemocy domowej. Analiza czynników i faktorów jako źródet agresji i przemocy domowej miała charakter dymorficzny. Analizie i penetracji poddano dwa obszary: okres prenatalny, czyli tzw. ,rodzacej się agresji i przemocy" oraz obszar czynników tkwiacych w środowisku rodzinno-domowym jednostki. Ze względu na wielość i różnorodność faktorów tkwiacych w tych obszarach, odniesiono się do czynników o charakterze typowo destrukcyjnym (patologicznym), jak np. nadużywanie alkoholu, jak również do czynników nieposiadajacych znamion patologii, jak np. bezrobocie. Liczne przywotywane eksploracje wskazuja, że agresja i przemoc domowa ma swoje podtoże $w$ zintegrowanych czynnikach makro- $i$ mikrospolecznych, tworzacych niekiedy ciagi pejoratywnych faktorów wyzwalajacych agresję i przemoc domowa. Analizujac uwarunkowania zachowań agresywnych zasygnalizowano również wybrane implikacje rozwoju i funkcjonowania jednostki, głównie dzieci.

Stowa kluczowe: agresja, przemoc, rodzina, jednostka.

1 Małgorzata Przybysz-Zaremba - dr hab. w zakresie nauk społecznych (pedagogika), prof. Uniwersytetu Kardynała Stefana Wyszyńskiego w Warszawie. Zainteresowania naukowe skupiają się wokół pedagogiki społecznej, resocjalizacyjnej, pedagogiki rodziny oraz pracy socjalnej. 


\section{Celem wprowadzenia. Agresja i przemoc domowa - amplituda zjawiska}

Agresja $^{1}$ i przemoc domowa ${ }^{2}$ coraz bardziej rozszerza się. Jest ona kierowana nie tylko w stosunku do osób dorosłych, ale również i dzieci, przyjmując rozmaite wymiary i kształty. Z raportu międzynarodowej organizacji UNICEF wynika, że $640 \mathrm{mln}$ dzieci na świecie nie posiada bezpiecznego dachu nad głową․ Międzynarodowe badania wskazują, że ponad $80 \%$ dzieci na świeci doświadcza fizycznej agresji i przemocy w rodzinie ${ }^{4}$. W Stanach Zjednoczonych rocznie rejestruje się około tysiąc czterysta przypadków zgonów dziecięcych, których przyczyną jest przemoc ze strony dorosłych. Z kolei w Rosji statystyki przemocy domowej kierowanej w stronę dzieci i młodzieży, które $\mathrm{z}$ tego powodu umierają, kształtują się na poziomie 2-2,5 tysiąca rocznie. Około $2 \mathrm{mln}$ dzieci do czternastego roku życia systematycznie doświadcza przemocy ze strony rodziców, a ponad 50

1 Agresja to „celowe $i$ świadome zachowanie fizyczne lub werbalne, podejmowane przeciwko komuś lub czemuś, którego celem jest wyrządzenie krzywdy lub zniszczenie”podaję za: P. G. Zimbardo, R. J. Gerrig, Psychologia i życie. Warszawa 2011, s. 346.

2 Przemoc to ,ciag zachowań o charakterze zamierzonym i instrumentalnym, a jej celem jest zniewolenie ofiary, wyeliminowanie jej suwerennych myśli i działań oraz podporządkowanie ofiary żądaniom i potrzebom sprawcy”, podaję za: J. Mazur, Przemoc $w$ rodzinie. Teoria i rzeczywistość. Warszawa 2002, s. 13. Zgodnie z ustawą z dnia 29 lipca 2005 r. o przeciwdziałaniu przemocy w rodzinie (Dz. U. z 2010 r., nr 125 poz. 842) przemoc $w$ rodzinie należy traktować jako ,jednorazowe albo powtarzające się umyślne działanie lub zaniechanie naruszające prawa lub dobra osobiste osób, [o których mowa $\mathrm{w}$ art. 2 pkt. $2 \mathrm{w} / \mathrm{w}$ ustawy - przez określenie członek rodziny należy rozumieć osobę najbliższą w rozumieniu art. $115 \S 11$ ustawy z dnia 6 czerwca 1997 r. Kodeks Karny (Dz. U. Nr 88, poz. 553, z późn. zm.), a także inną osobę wspólnie zamieszkującą lub gospodarującą], w szczególności narażające te osoby na niebezpieczeństwo utraty życia, zdrowia, naruszające ich godność, nietykalność cielesną, wolność, w tym seksualną, powodujące szkody na ich zdrowiu fizycznym lub psychicznym, a także wywołujące cierpienia i krzywdy moralne u osób dotkniętych przemocą". Zob. szerzej: M. PrzybyszZaremba, Uwarunkowania zachowań agresywnych i/lub przemocowych wystepujacych $w$ rodzinie - wybrane konteksty. Spoleczno-demograficzny model agresora $-w$ świetle badań własnych, w: Społeczno-ekonomiczne uwarunkowania rozwoju rodziny, red. K. Szczepańska-Woszczyna, M. Hronec, Dąbrowa Górnicza 2014, s. 201-214.

3 Podaję za: T. Pilch, Miliard dzieci bez szczęścia, „Chowanna” 2010, 1 (34), s. 41-50.

4 R. Giacaman, H. S. Shannon, H. Saab, N. Arya, W. Boyce, Individual and collective exposure to political violence: Palestinian adolescents coping with conflict. „The European Journal of Public Health" 2007, t. 17, nr 4, s. 361-368. 
tys. rocznie ucieka z domu przed agresją i przemocą ${ }^{5}$. W Polsce w roku 2014 ponad 100 tys. osób doświadczyło przemocy domowej, z czego ponad 70 tys. stanowiły kobiety, a ponad 21 tys. małoletni ${ }^{6}$. Polskie statystyki policyjne ${ }^{7}$ wskazują, że ofiarami przemocy domowej są najczęściej słabsi, tj. dzieci i kobiety. Potwierdzają ten fakt również badania międzynarodowe. I tak, np. z badań prowadzonych wśród mieszkańców Litwy wynika, że w co trzeciej rodzinie mamy do czynienia z przemocą domową, której $90 \%$ przypadków, ofiarami są kobiety ${ }^{8}$. Z kolei raport z roku 2014 przygotowany przez Agencję Praw Podstawowych Unii Europejskiej ${ }^{9}$ wskazuje, że prawie jedna trzecia badanych kobiet stwierdziła, że osobiście doświadczyła przemocy, a prawie $50 \%$ kobiet przyznało, że posiada wiedzę na temat przemocy występującej we własnej rodzinie i wśród przyjaciół; $24 \%$ badanych wskazało, że zna przypadki przemocy wśród współpracowników. Ponad 80\% badanych uważa, że przemoc jest zjawiskiem powszechnym. Prawie $90 \%$ ofiar doświadcza przemocy psychicznej; prawie 50\% przemocy fizycznej; około $30 \%$ przemocy ekonomicznej a ponad $10 \%$ przemocy seksualnej ${ }^{10}$.

Badania amerykańskie wskazują, że ponad 20\% kobiet i około $10 \%$ mężczyzn pada ofiarą agresji i przemocy w ciągu życia, ze strony swojego partnera/partnerki. Ponad $60 \%$ gwałtów i napaści seksualnych spotyka kobiety ze strony znanych im mężczyzn. Według opublikowanych danych WHO, aż 20-50\% kobiet informuje, że były ofiarami przemocy ze strony partnera ${ }^{11}$.

5 E. R. Iarskaia-Smirnova, P. V. Romanov, E. P. Antonova, Domestic Violence Against Children. Strategies of Explanation and Counteraction, „Russian Education and Society” 2008, t. 50, nr 11, s. 20-35.

${ }^{6}$ Zob. szerzej: http://statystyka.policja.pl/st/wybrane-statystyki/przemoc-w-rodzinie/50863,Przemoc-w-rodzinie.html [dostęp. 18.08.2015].

7 Zgodnie z procedurą ,niebieskiej karty” w roku 2014 policja zarejestrowała około 11,5 tys. przypadków przemocy domowej, której ofiarami byli mężczyźni. Zob. http://statystyka.policja.pl/st/wybrane-statystyki/przemoc-w-rodzinie/50863,Przemoc-w-rodzinie. html [dostęp. 18.08.2015].

8 L. Narkauskaite, A. Krupskienė, Smurtas - visuomenès sveikatos problema. Smurto samprata, [w:] Smurto paplitimas ir jo prevencija Lietuvoje, Vilnius 2011, s. 2-8.

9 Smurtas prieš moteris, Europos tyrimas, „Europos Sąungos pagrindinių teisių agentūros ataskaita", 2014.

10 Smurto prieš moteris šeimoje analizè ir smurto šeimoje auku būklès įvertinimas: tyrimo ataskaita, BGI Consulting, 2008. Zob. J. Sadauskas, A. Katkonienè, M. PrzybyszZaremba, Przemoc $w$ rodzinie wobec kobiet - na przykładzie Litwy - tekst złożono do druku.

11 Podaję za: M. Dąbkowska, Psychiatryczne następstwa przemocy domowej, „Psychiatria w Praktyce Ogólnolekarskiej” 2005, t. 5, nr 3, s. 103-108. 
Źródeł agresji i przemocy domowej jest nieskończenie wiele. Znajdują one swoje podłoże; zarówno w faktorach tkwiących w systemach wewnątrzrodzinnych, jak i generatorach makrospołecznych. Henryk Cudak ${ }^{12}$ wskazuje, że czynniki makrospołeczne często w sposób niebezpieczny oddziałują na rodzinę i/lub w jej obrębie, tworząc sytuacje dynamizujące zachowania agresywne oraz przemocowe. Czynniki te niejednokrotnie stanowią zintegrowane zespoły asumptów, które mają swoje podłoże w przeobrażeniach i rewolucji globalizującego się świata.

W tekście analizie i penetracji poddano dwa obszary, jako źródła czynników wyzwalających zachowania agresywne i przemocowe, tj. okres (obszar) prenatalny człowieka, czyli okres tzw. ,,rodzacej się agresji i przemocy” oraz obszar faktorów/ czynników tkwiących w środowisku rodzinno-domowym. Analiza czynników tkwiących w tych obszarach dotyczy najważniejszych w moim przekonaniu asumptów/faktorów, które wyzwalają agresję i przemoc w rodzinie, nie tylko w stosunku do dzieci i dorosłych, ale także dzieci w stosunku do dorosłych. Ze względu na ich wielość i różnorodność, a przede wszystkim oddziaływanie na nie innych czynników o charakterze makrospołecznym, dokładna, a zarazem pogłębiona ich analiza jest niemożliwa. Stąd też moja uwaga skupiona zostanie na wybranych czynnikach odnoszących się do wskazanych obszarów.

\section{Dymorficzne obszary uwarunkowań agresji i przemocy domowej - zarys deskrypcji}

\section{Okres prenatalny jako obszar „rodzqcej się agresji i przemocy”}

Od momentu zapłodnienia do precyzyjnego rozwoju płodu mija nieco czasu. Okres ten ma zatem kardynalne znaczenie zarówno dla prawidłowego kształtowania się płodu - jak i po urodzeniu dziecka - dla jego rozwoju, przebiegu procesu socjalizacyjno-wychowawczego, wrastania w grupę społeczną, a także umiejętności funkcjonowania w życiu dorosłym. Prawidłowe dbanie o zdrowie kobiety będącej w ciąży jest tu niezwykle ważne. Liczne eksploracje potwierdzają, że spożywanie przez kobiety w ciąży różnych „używek” (głównie alkoholu i papierosów) pejoratywnie oddziałuje na rozwój płodu, a później dalszy rozwój dziecka. Pomimo świadomości kobiet wiele badań wskazuje na częstotliwość spożywania, a niekiedy nadużywania tych używek przez ciężarne. W dotychczasowych badaniach przyjęto kryterium pięć drinków na dobę, określające nadużywanie przez kobiety ciężarne alkoholu. Odnosząc się do tego kryterium, badania brazylijskie

12 H. Cudak, Dysfunkcje rodziny i jej zagrożenia opiekuńczo-wychowawcze, „Pedagogika Rodziny” 2011, 1(2), s. 7-10. 
wskazują, że $40 \%$ kobiet ciężarnych spożywa etanol, a od 7\% do 23\% spośród $\mathrm{z}$ nich nadużywa $\mathrm{go}^{13}$. W Chile około $60 \%$ badanych przyznało się do konsumpcji alkoholu, a $30 \%$ z nich nadużywa $\mathrm{go}^{14}$. Natomiast w Danii prawie $40 \%$ badanych kobiet w ciąży spożywa alkohol, a ponad $25 \%$ przekracza dopuszczalną w tym kraju dawkę jednego drinka na dobę $e^{15}$.

Badania wskazują, że po około 40-60 minutach poziom alkoholu we krwi dziecka jest taki sam, jak we krwi matki. Dziecko rozwijające się w macicy nie jest w stanie szybko wyeliminować toksyn, stąd też znacznie dłużej jest ono narażone na ich działanie. Wskazano na związek pomiędzy oddziaływaniem alkoholu na płód dziecka a jego dalszym rozwojem i życiem. Negatywnych implikacji rozwoju płodu poddawanego oddziaływaniom alkoholu jest wiele ${ }^{16}$. Można je określić jako poalkoholowe spektrum zaburzeń rozwojowych (fetal alcohol spectrum disorder, $F A S D$ ) - spektrum wrodzonych anomalii strukturalnych i neurokognitywnych oraz behawioralnych. Dzieci z kompletnym fenotypem anomalii fizycznych, opóźnieniem wzrostu i nieprawidłowościami rozwojowymi ośrodkowego układu nerwowego, definiowane są jako dzieci z płodowym zespołem alkoholowym (fetal alcohol syndrome, $F A S$ ). Wyróżnia się także, inne kategorie zaburzeń poalkoholowych, m.in. częściowy FAS ( partial fetal alcohol syndrome, PFAS), poalkoholowe wady wrodzone (alcohol-related birth defects, $A R B D$ ) i poalkoholowe zaburzenia neurorozwojowe (alcohol-related neurodevelopmental disorder, ARND) ${ }^{17}$. Jednym z najczęściej spotykanych zaburzeń jest występowanie u dzieci zespołu FASD, którego symptomy w okresie wzrastania uwidaczniają się, m.in. w zaburzeniach rozwoju psychicznego, które przekłada się na słabe wyniki w nauce ${ }^{18}$, przejawach

13 U. Kesmodel, P.S, Kesmodel, A. Larsen, N. J. Secher, Use of alcohol and illicit drugs among pregnant Danish women, 1998 Scand, ,Journal of Public Health” 2003, t. 31, s. 5-11.

14 Podaję za: W. Szychta, M. Skoczylas, T. Laudański, Spożywanie alkoholu i palenie tytoniu przez kobiety w ciąży - przegląd badań, „Perinatologia, Neonatologia i Ginekologia” 2008, t. 1, z. 4, s. 309-313.

15 U. Kesmodel, P. S. Kesmodel, A. Larsen, N. J. Secher, Use of alcohol and illicit drugs..., dz. cyt., s. 5-11.

16 Szerzej na temat skutków działania alkoholu na rozwój płodu zob: J. Salmon, Fetal alcohol spectrum disorder: New Zealand birth mothers' experiences, „Canadian Journal of Clinical Pharmacology" 2008, nr 15, s. 191-213.

17 M. Klecka, M. Janas-Kozik, I. Krupka-Matuszczyk, Rozwój diagnostyki poalkoholowego spektrum zaburzeń rozwojowych - przegląd narzędzi diagnostycznych, „Psychiatria i Psychologia Kliniczna” 2010, 10 (4), s. 298-302.

18 Badania przeprowadzone wśród dzieci w wieku wczesnoszkolnym wskazują, że dzieci poddawane w okresie prenatalnym działaniu alkoholu mają ubytek 7 punktów IQ. Dzieci te w stosunku do dzieci z grupy kontrolnej są znacznie słabsze w zakresie czytania, 
trudności wychowawczych, zachowaniach agresywnych i/lub przemocowych, a w konsekwencji niedostosowaniu społecznym ${ }^{19}$ i wykolejeniu. U dzieci tych występuje zwiększone ryzyko wystąpienia nadpobudliwości psychoruchowej $(\text { ADHD })^{20}$. Tzw. „,wtórne zaburzenia”, jakich doświadcza dziecko z FASD, ujawniają się również w problemach funkcjonowania społecznego, nieodpowiednich zachowaniach seksualnych, a także różnego rodzaju uzależnieniach ${ }^{21}$.

ortografii, dodawania, odejmowania, świadomości fonologicznej i innych testów wczesnej umiejętności. Zob. Asher Ornoy, Zivanit Ergaz, Alcohol Abuse in Pregnant Women: Effects on the Fetus and Newborn, Mode of Action and Maternal Treatment, „International Journal of Environmental Research and Public Health" 2010 Feb; 7(2), s. 364-379, doi: 10.3390/ ijerph7020364.

19 Termin niedostosowanie społeczne został opracowany przez Światowy Związek Opieki nad Dziećmi i Młodzieżą. W Polsce jako pierwsza określenia tego użyła w roku 1959 Maria Grzegorzewska, która terminem tym objęła „zespół wszystkich nieletnich wymagających specjalnych metod wychowawczych". Pojęcie niedostosowanie spoleczne określane i definiowane jest przez pedagogów, psychologów, socjologów, psychiatrów, a nawet prawników, stąd też w zależności od punktu widzenia badaczy pojęcie to jest różnie definiowane i analizowane, ma ono charakter wieloznaczny. W najprostszymi tłumaczeniu niedostosowanie społeczne odnosi się do różnych zaburzeń w społecznej adaptacji jednostki. Jest to ,zaburzenie charakterologiczne o niejednolitych objawach, spowodowane niekorzystnymi zewnętrznymi lub wewnętrznymi warunkami rozwoju. Wyrażające się długotrwałymi trudnościami w dostosowaniu się do normalnych warunków społecznych”. Głównymi symptomami niedostosowania społecznego są: „tendencje społecznie destruktywne, chęć wyżycia się w akcji społecznie destruktywnej, nieżyczliwy stosunek do człowieka, zrzucanie winy na innych, brak hamulców, sugestywność, nieumiejętność wyjścia z trudnej sytuacji” (zob. B. Urban, Zaburzenia w zachowaniu i niedostosowanie społeczne w świetle współczesnych wyników badań, w: Resocjalizacja, red. B. Urban, J. M. Stanik, t. 1, Warszawa 2008, s. 138; M. Przybysz-Zaremba, Wokót wybranych dysfunkcji rodziny jako uwarunkowań niedostosowania społecznego dzieci i młodzieży-implikacje i działania, w: Socialni pedagogika ve sluzbe cloveku a spolecnosti, red. S. Neslusanova, I. Emmerova, E. Jarosz, Brno 2014, s. 520-533.

20 R. D. Goodwin, K. Keyes, N. Simuro, Mental disorders and nicotine dependence among pregnant women in the United States, „Obstetrics \& Gynecoly” 2009, nr 109, s. 875883; W. Szychta, M. Skoczylas, T. Laudański, Spożywanie alkoholu i palenie tytoniu przez kobiety w ciąży - przegląd badań, „Perinatologia, Neonatologia i Ginekologia” 2008, t. 1, z. 4, s. 309-313.

${ }^{21}$ E. Clark, J. Lutke, P. Minnes, H. OuelletteKuntz, Secondary disabilities among adults with fetal alcohol spectrum disorder in British Columbia, „Journal of FAS International” 2004, t. 2(e13), s. 1-12. 
Obok alkoholu bardzo niebezpiecznym dla kształtowania się płodu i rozwoju dziecka jest palenie tytoniu przez kobiety ciężarne. Badania nad skutkami działania dymu tytoniowego (papierosowego) na rozwój płodu oraz bezpośrednio po narodzinach, prowadzili m.in. C. Yochum, S. Doherty-Lyon, C. Hoffman, M. M. Hossain, J. T. Zelikoff oraz J. R. Richardson ${ }^{22}$ na zwierzętach. Myszy będące w ciąży były narażone na oddziaływanie dymu papierosowego od dnia zdiagnozowania ciąży do momentu porodu przez cztery godziny dziennie. Stężenie ekwiwalentu kotyniny ${ }^{23}$ odpowiadało wypaleniu jednej paczki papierosów dziennie (25 $\mathrm{ng} / \mathrm{ml}$ poziom kotyniny w osoczu). Szczeniaki odstawiono od matki w 21 dniu od porodu, a ich zachowanie poddano badaniu, gdy miały cztery tygodnie życia, a następnie, gdy miały od 4 do 6 miesięcy. Zarówno wśród szczeniaków płci męskiej, jak i żeńskiej, wykazano wzrost aktywności ruchowej w czasie dojrzewania i dorosłości. Owe zaburzenie poddano leczeniu za pomocą metylofenidatu ${ }^{24}$, który szczególnie u płci męskiej zmniejszył latencję do ataku. Badania te wskazują, że pejoratywne wpływy dymu papierosa w okresie prenatalnym kształtują zmiany behawioralne u myszy, które są analogiczne do danych uzyskanych w badaniach epidemiologicznych, łączących palenie papierosów przez matki będące w ciąży, z zaburzeniami rozwoju ukladu nerwowego narodzonych dzieci.

Podsumowując powyższe analizy i badania należy wskazać, że wszystkie osoby dotknięte FASD, narażone są na różnego rodzaju zaburzenia i choroby, których wymiar częstokroć ma charakter nader destrukcyjny. Ich rozwój zależny jest od wielu różnorakich czynników, tkwiących w obszarach życia i funkcjonowania jednostki.

22 C. Yochum, S. Doherty-Lyon, C. Hoffman, M. M. Hossain, J. T. Zelikoff, J. R. Richardson, Prenatal cigarette smoke exposure causes hyperactivity and aggressive behavior: role of altered catecholamines and BDNF, „Experimental Neurology” [Exp Neurol] 2014 April, t. 254, s. 145-52.

23 Kotynina to główny metabolit nikotyny. Około 70-80\% nikotyny dostarczonej do organizmu ludzkiego zostaje przekształcona do kotyniny. Zob. J. M. Nowak, A. Żuryń, A. Grzanka, Kotynina - metabolizm, zastosowanie jako biomarker $i$ wptyw na organizm człowieka, „Postępy Higieny i Medycyny Doświadczalne” (online), 2012, nr 66, s. 996-1005.

24 Metylofenidat to organiczny związek chemiczny, lek o działaniu stymulującym z grupy fenetylamin dostępny handlowo w Polsce pod nazwą Concerta. Używany jest w leczeniu ADHD i narkolepsji oraz przy wyprowadzaniu z narkozy (podaję za: $w w w$. szkolnictwo.pl). 


\section{Obszar rodzinno-domowy}

Środowisko rodzinne jest prymarnym, a zarazem priorytetowym obszarem życia i funkcjonowania dziecka. To w rodzinie kształtuje ono swoje umiejętności, nawyki, konstruuje własny system wartości. Uczy się wzorów społecznego postępowania, kształtuje postawy wobec rodziny, wobec innych ludzi, wobec samego siebie.

Każda prawidłowo funkcjonująca rodzina powinna względem dziecka wypełniać swoje zadania i funkcje. Stanisław Kawula ${ }^{25}$ wskazuje na cztery główne z nich: funkcję biologiczno-opiekuńczą, kulturalno-towarzyską, ekonomiczną oraz wychowawczą. Przykry jest jednak fakt, iż każda z tych funkcji jest zaburzona, a niektóre z nich „zatracone” (nie są realizowane). Andrzej Olubiński ${ }^{26}$ prowadząc badania nad realizacją funkcji, jakie powinna wypełniać rodzina, wskazuje, że zaledwie nieco ponad $10 \%$ badanych rodzin wypełnia funkcje podstawowe. Wyniki badań autora można odnieść do obserwacji życia i funkcjonowania współczesnych rodzin, które nieustannie podlegają transformacji globalizującego się świata. Jednym z głównych problemów, którego doświadcza rodzina, a który zintegrowany jest z innymi faktorami makrospołecznymi, problemami i dysfunkcjami - należy uznać, jako asumpt przejawów agresji i przemocy - jest brak pracy (bezrobocie) ${ }^{27}$. Jadwiga Izdebska ${ }^{28}$ bezrobocie dołączyła do syndromu 3D (bezrobocie, bezdomność, bieda), które prowadzi do biedy, a w konsekwencji bezdomności (i/lub odwrotnie). Syndrom 3D niejednokrotnie wiąże się z występowaniem innych zjawisk destrukcyjnych, np. alkoholizmem, narkomanią, co implikuje dezorganizacją struktury systemu rodziny. Członkowie rodziny, uzewnętrzniają różnorakie destrukcyjno-patologiczne zachowania. Jednym z najbardziej widocznych jest nadużywanie alkoholu (problem alkoholowy). Polska pod tym względem charakteryzuje się najwyższym wskaźnikiem spożycia alkoholu (około 70\% spożywanych napojów alkoholowych to napoje spirytusowe), co tym

25 S. Kawula, J. Brągiel, A. Janke, Pedagogika rodziny, Toruń 2005, s. 57.

26 A. Olubiński, Wspótpraca rodziny i szkoły jako funkcja życia społecznego, w: Płaszczyzny wspótpracy szkoły ze środowiskiem lokalnym, red. L. Hurło, Łódź 2011, s. $35-43$.

27 Na koniec marca 2015 r. stopa bezrobocia w Polsce kształtowała się na poziomie $11,7 \%$ cywilnej ludności aktywnej zawodowo. GUS, Bezrobocie rejestrowane, I kwartat 2015 r., Warszawa 2015, s. 14.

28 Dziecko $w$ rodzinie $i$ środowisku rówieśniczym. Wybrane zagadnienia i źródła z pedagogiki społecznej, red. J. Izdebska, Białystok 2003, s. 79. 
samym lokuje ją w pierwszej dziesiątce krajów świata ${ }^{29}$. Heterogeniczny wymiar badań prowadzonych nad skutkami nadużywania alkoholu dowodzi, że jest on „wyzwalaczem” agresji i przemocy. Badania Instytutu Psychologii Zdrowia PTP wskazują, że w około $70 \%$ rodzin, w których występuje problem nadużywania alkoholu doświadcza agresji i przemocy ze strony pijącego ${ }^{30}$. Skutki konsolidacji nadużywania alkoholu oraz agresji i przemocy są niebywałe dla całego systemu rodziny, a szczególnie dla dzieci w niej przebywających. Mikołaj Winiarski ${ }^{31}$ przedstawia charakterystykę zaburzeń, występujących u dzieci przebywających w rodzinie z problemem nadużywania alkoholu, są to m.in.: zaburzenia psychiczne, ujawniające się w skrajnych emocjach, nieumiejętności funkcjonowania $\mathbf{w}$ relacjach ze środowiskiem społecznym (z bliskimi, rówieśnikami, otoczeniem); wczesne podejmowanie inicjacji alkoholowej, nikotynowej, bądź narkomanicznej. Dzieci te, znacznie częściej przejawiają symptomy niedostosowania społecznego ( $w$ tym zachowania agresywne) o różnym wymiarze i formie, a w konsekwencji doświadczają wykolejenia społecznego. Zdaniem L. A. Benvegnu, A. G. Fassa, L. A. Facchini, D. H. Wegman oraz M. M. Dall'Agnol ${ }^{32}$ zachowania te dwa razy częściej przejawiane są przez dzieci i młodzież, wobec których rodzice stosowali restrykcyjne metody wychowawcze, w tym kary fizyczne.

Mantymaa Mirjami, Puura Kaija, Luoma Ilona i in.$^{33}$ wskazują, że zaburzenia w zachowaniu, a także wszelkie problemy zdrowotne dzieci do 5 roku życia, związane są z czynnikami tzw. ryzyka, tkwiącymi w systemie rodzinnym oraz w samym dziecku:

29 M. Przybysz-Zaremba, Problem nadużywania alkoholu jako determinant motywacji do podejmowania przez kobiety aktywności edukacyjno-zawodowej, w: Rodzina. Przeobrażenia, problemy, pomoc, red. I. M. Kijowska, M. Przybysz-Zaremba, Elbląg 2013, s. $157-159$.

30 Podaję za: Państwowa Agencja Rozwiązywania Problemów Alkoholowych, Narodowy Program Profilaktyki i Rozwiąywania Problemów Alkoholowych na lata 2006-2010, Warszawa, s. 8.

31 M. Winiarski, Rodzina - szkoła-środowisko lokalne. Problemy edukacji środowiskowej, Warszawa 2000.

32 L. A. Benvegnu, A. G. Fassa, L. A. Facchini, D. H. Wegman, M. M. Dall' Agnol, Work and behavioural problems in children and adolescents, „International Journal of Epidemiology" 2005, nr 34 (6), s. 1417-1424.

33 M. Mantymaa, K. Puura, I. Luoma, R. Latva, R. K. Salmelin, T. Tamminen, Predicting Internalizing and Externalizing Problems at Five Years by Child and Parental Factors in Infancy and Toddlerhood, „Child Psychiatry and Human Development” 2012, t. 43, nr 2, s,153-170. 
1) ryzyko zwiazane ze zdrowiem dziecka: problemy z dzieckiem, temperament niemowlęcia i wczesne objawy emocjonalne $\mathrm{i}$ behawioralne dziecka (uzewnętrznianie i internalizacja);

2) ryzyko rodzicielskie: psychopatologia rodzicielska, stres rodzicielski, percepcja dziecka przez matkę;

3) ryzyko rodzinne: status społeczno-ekonomiczny rodziny, problemy małżeńskie rodziców, zaburzone relacje, przemoc, patologie i inne problemy rodziny.

Przywołane badania wskazują, że rodzina szczególnie w pierwszych latach życia i rozwoju dziecka jest niezwykle ważna. Tymczasem rzeczywistość często kształtuje zupełnie inny obraz. Dzieci i młodzież sięgające/ca po alkohol bądź narkotyki, które są podłożem zachowań agresywnych i/lub przemocowych, często bardzo brutalnych, ,nie maja domu, ani rodziny”. Brak domu traktuję tu nader metaforycznie, bo przecież dom, to nie tylko budynek, ale ludzie w nim przebywający, relacje między nimi, wsparcie, miłość, ciepło. Literatura psychologiczna ${ }^{34}$ wskazuje na szereg czynników, które oddziałując na młodych ludzi, przyczyniają się do ujawniania przez nich agresji i przemocy (w tym do sięgania po alkohol, narkotyki, bądź dopalacze). Pierwsza grupa stanowi faktory osobiste, które są niezwykle zmienne, jak np. poczucie własnej wartości, konstruowanie samooceny lub wcześniej doświadczane negatywne zachowania ze strony dorosłych (np. w okresie dzieciństwa dziecko było ofiarą nadużyć seksualnych). Druga grupa czynników związana jest z przebiegiem relacji interpersonalnych w środowisku społecznym, tj. w rodzinie, grupie rówieśniczej, szkole. Grupa trzecia zaś odnosi się do pejoratywnego oddziaływania środowiska społecznego, a właściwie grupy społecznej, w której dominują zachowania nieakceptowane społecznie, a dostępność do alkoholu, czy narkotyków jest bardzo łatwa. Młodzi ludzie w grupie tej znajdują oparcie i akceptację - są afirmowani ze wszystkimi swoimi zaletami i wadami. Konstruują swój własny „świat”, własne życie nie w rodzinie, ale w konkretnej grupie rówieśniczej.

Współczesna rodzina, jak to określił Stanisław Kawula ${ }^{35}$, doświadcza dyferencjacji norm i wartości. Dzieci bardzo wcześnie skazane są na bycie dorosłym, a ich rodzice pochłonięci są pracą zawodową, która niejednokrotnie odbywa się poza miejscem zamieszkania. Współcześnie mamy do czynienia z zarobkową migracją zagraniczną rodziców, która skupia się na realizacji funkcji ekonomicznej

34 P. Martínez-Lanz, A. González-González, D. Betancourt Ocampo, Domestic Violence and Alcohol and Illegal Drugs Consumption in Mexican Youth, „Journal of Health Science” 2014, t. 2, s. 466-469.

35 S. Kawula, Pedagogika społeczna. Dzisiaj i jutro, 2012. 
rodziny, a poważnie zaburza funkcję socjalizacyjno-wychowawczą. Zdaniem Leona Dyczewskiego ${ }^{36} \mathrm{w}$ rodzinie niezwykle ważne są relacje, które wiążą się $\mathrm{z}$ więzią rodzinną, ujawniającą się w różnego rodzaju stosunkach pomiędzy małżonkami/partnerami, rodzicami-dziećmi, zależnościach i postawach przyjmowanych przez członków rodziny. W rodzinach doświadczających migracji zarobkowej trudno mówić o prawidłowych relacjach pomiędzy członkami rodziny, szczególnie gdy chodzi o dzieci. Wioleta Danilewicz ${ }^{37}$ wskazuje, że fizyczna rozłąka rodzica/ rodziców z dzieckiem/dziećmi prowadzi do trwałego „pęknięcia” relacji: dziecko-rodzic i vice versa. Dziecko w taki sposób - można to potraktować, że ,za zgoda rodziców" - poszukuje własnych wartości, przekonań i oparcia. W stosunku do rodziny/rodziców, przybiera postawę pasywną - ,nic jemu się nie chce robić, bo nic w zamian od niej nie otrzymuje". Zachowania destrukcyjno-patologiczne są jedynymi, które sprawiają mu radość. Przejawiana agresja i przemoc może być „wołaniem" do rodziców o pomoc, bądź sygnalizowaniem: ,ja tu jestem!!!, potrzebuję Was, potrzebuję pomocy!!!’. Często jednak bywa tak, że rodzina nie dostrzega tych sygnałów, ponieważ rodziców nigdy nie ma w domu. Podobna sytuacja może mieć miejsce, gdy rodzina doświadcza choroby. Wówczas cała uwaga rodziców skupia się na osobie chorej. Pozostali członkowie rodziny skazani są wyłącznie na siebie. Linda Loon, Monique Ven oraz in. ${ }^{38}$ wskazują, że zachowania dzieci w rodzinach, w których występują chorzy członkowie (szczególnie dotyczy to chorób nieuleczalnych, nowotworowych), znacznie rzadziej są monitorowane, co przekłada się na większą liczbę podejmowanych przez nie zachowań problemowych, do których bez wątpienia zaliczyć należy agresję i przemoc.

Konsekutywnym problemem, który niejednokrotnie staje się podłożem dla agresji i przemocy, są kryzysy ${ }^{39}$ rodziny, ich wymiar ma charakter heterogeniczny. Transformacja społeczno-gospodarcza jest tu istotnym generatorem doświadczania kryzysu. W rodzinie może mieć on charakter incydentalny (sytuacyjny),

36 L. Dyczewski, Więź między pokoleniami w rodzinie. Lublin 2002, s. 12.

37 W. Danilewicz, Sytuacje życia dzieci w rodzinach migracyjnych, Białystok 2006, s. $192-194$.

38 L. Loon, M. Ven, K. Doesum, C. Witteman, C. Hosman, The Relation Between Parental Mental Illness and Adolescent Mental Health: The Role of Family Factors, „Journal of Child \& Family Studies" 2014, t. 23. z. 7, s. 1201-1214.

39 Kryzys to wydarzenie cykliczne (powtarzające się), mające charakter długotrwałego stresu (rozciągnięte w czasie). Inna definicja określa kryzys jako przejściowy stan nierównowagi wewnętrznej, spowodowanej zaistnieniem krytycznego wydarzenia, bądź wydarzenia życiowego, wymagającego istotnych zmian i rozstrzygnięć. (Podaję za: B. M. Nowak, Rodzina w kryzysie. Studium resocjalizacyjne, Warszawa 2011, s. 36). 
egzystencjalny, endogenny, przewlekły bądź złożony ${ }^{40}$. Współcześnie życie i funkcjonowanie społeczne rodziny jest bardzo utrudnione. Wiele niebezpiecznych czynników społecznych oddziałuje na nią w sposób dynamiczny, implikując wieloma problemami i dysfunkcjami w obszarze rodzinno-domowym. Jako przykład pozwolę sobie przywołać badania, które prowadziłam na temat społeczno-demograficznego modelu agresora, obalające dotychczasowy mit mówiący o tym, że agresorem jest osoba z najniższym wykształceniem, wykonująca pracę fizyczną. $Z$ badań ${ }^{41}$ wynika, że agresja i przemoc rodzinna przejawiana jest najczęściej przez mężczyzn do 30. roku życia, z wyższym wykształceniem, wykonujących pracę umysłową i zamieszkujących na terenach małomiasteczkowych i/lub wiejskich. Model ten przedstawia człowieka wykształconego, który w wyniku doświadczania wielu stresów, napięć i problemów związanych z pracą zawodową, sięga po alkohol, a doświadczane napięcia i stresy ,wyładowuje” na najbliższych.

Przedstawione faktory tkwiące w obszarze rodzinno-domowym, jako źródła przejawów agresji i przemocy, nie stanowią holistycznej analizy, gdyż ze względu na ich wielość, różnorodność, a przede wszystkim ich współzależność, stanowią zespoły kompleksów częstokroć ze sobą zintegrowanych, stąd też dokładna ich analiza nastręcza wiele trudności. Istotnym spostrzeżeniem jest tu jednak fakt, iż jedne faktory (głównie o charakterze dysfunkcyjno-patologicznym, chociaż nie jest to regułą) wyzwalają drugie i odwrotnie, tworząc w ten sposób ciągi wzajemnie konstruowanych pejoratywnych faktorów i asumptów. O. Sde Mangueira oraz M. V. Lopes ${ }^{42}$ na podstawie przeprowadzonych badań wskazują, że problem nadużywania alkoholu w rodzinie ma swoje źródło w zróżnicowanych czynnikach dysfunkcyjnych, tkwiących w rodzinie. A zatem, agresja i przemoc występujące w rodzinie; może być przyczyną nadużywania alkoholu, ale i vice versa.

\section{Podsumowanie}

Przywoływane analizy, badania i interpretacje prowadzone wokół uwarunkowań agresji i przemocy domowej wskazują na dymorficzny jej wymiar. Agresja

40 B. M. Nowak, Rodzina w kryzysie. Studium resocjalizacyjne, Warszawa 2011, s. 36.

41 Szersze wyniki badań zostały opublikowane w: M. Przybysz-Zaremba, Uwarunkowania zachowań agresywnych i/lub przemocowych występujacych $w$ rodzinie - wybrane konteksty. Społeczno-demograficzny model agresora - w świetle badań własnych, w: Społeczno-ekonomiczne uwarunkowania rozwoju rodziny, red. K. Szczepańska-Woszczyna, M. Hronec, Dąbrowa Górnicza 2014, s. 201-214.

42 O. Sde Mangueira, M. V. Lopes, Dysfunctional family in the context of alcoholism: conceptanalysis, „Revista Brasileira De Enfermagem” 2014, t. 67, nr 1, s. 149-54. 
i przemoc domowa mają swoje źródło w zróżnicowanych obszarach życia i funkcjonowania poszczególnych członków rodziny. Mogą być one związane z osobowością jednostki, z jej systemem wartości, różnymi zaburzeniami psychicznymi, które mają swoje podłoże w doświadczaniu wielu stresogennych sytuacji, choć często - jak wskazano w badaniach - dzieci już w okresie prenatalnym narażone są na wiele niebezpiecznych zachowań ze strony matki, jakie już w bardzo wczesnym okresie życia przyczyniają się do ujawniania przez nieh ${ }_{2}$ w przyszłości zachowań agresywnych. Współcześnie istotnym czynnikiem może być pozycja społeczna agresora, płeć, wiek, niewłaściwe relacje interpersonalne członków rodziny, bezpośrednie sytuacje pobudzające złe zachowanie, kłótnie, które mogą być implikacją oddziaływania wielu faktorów makrospołecznych. Rezydowanie w takiej rodzinie oddziałuje w sposób pejoratywny na wszystkich jej członków, a na dzieci w szczególności, ponieważ doświadczają one zaburzonego procesu socjalizacyjno-wychowawczego.

Podsumowując prowadzone analizy i przywoływane badania, dotyczące uwarunkowań agresji i przemocy domowej, można pokusić się o stwierdzenie, że „,agresja/przemoc domowa rodzi agresję/przemoc wśród dzieci, dorostych”, jest ona przekazywana z pokolenia na pokolenie, co tym samym konstruuje swoistego rodzaju ,,cykl rozwojowy agresji/przemocy”, ukazujący różnorodny wymiar zachowań agresywno-przemocowych w kolejnych pokoleniach. Agresja i przemoc domowa może przybierać różne rodzaje i formy, może być przejawiana zarówno w stosunku do osób dorosłych (partnera, partnerki, matki, żony), jak i w stosunku do dzieci. Dzieci, skazane na życie w rodzinie obarczonej wieloma kryzysami, problemami i patologiami, których podłożem są niejednokrotnie zintegrowane grupy czynników (najczęściej o charakterze pejoratywnym) makro- i mikrospołecznych, uczą się agresji i przemocy, którą przejawiają już w bardzo wczesnym okresie życia. W miarę wzrostu ujawniają coraz bardziej niebezpieczne zachowania, początkowo przejawiane w stosunku do rówieśników, później także w stosunku do osób dorosłych. Będąc dorosłymi tworzą model rodziny, w którym agresja i przemoc domowa, staje się codziennością.

\section{Bibliografia}

Benvegnu L. A., Fassa A. G., Facchini L. A., Wegman D. H., Dall' Agnol M. M., Work and behavioural problems in children and adolescents, „International Journal of Epidemiology" 2005, 34 (6)

Clark E., Lutke J., Minnes P., OuelletteKuntz H., Secondary disabilities among adults with fetal alcohol spectrum disorder in British Columbia, „Journal of FAS International" 2004, t. 2(e13) 
Cudak H., Dysfunkcje rodziny i jej zagrożenia opiekuńczo-wychowawcze, „Pedagogika Rodziny” 2011, 1(2).

Danilewicz W., Sytuacje życia dzieci w rodzinach migracyjnych, Wydawnictwo Trans Humana, Białystok 2006

Dąbkowska M., Psychiatryczne następstwa przemocy domowej, „Psychiatria w Praktyce Ogólnolekarskiej” 2005, tom 5, nr 3 ,

Dyczewski L., Więź między pokoleniami w rodzinie, Towarzystwo Naukowe KUL, Lublin 2002

Giacaman R., Shannon H. S., Saab H., Arya N., Boyce W., Individual and collective exposure to political violence: Palestinian adolescents coping with conflict, „The European Journal of Public Health” 2007, t. 17, nr 4

Goodwin R. D., Keyes K., Simuro N., Mental disorders and nicotine dependence among pregnant women in the United States, „Obstetrics \& Gynecoly” 2009, nr 109

Iarskaia-Smirnova E.R., Romanov P.V., Antonova E.P., Domestic Violence Against Children. Strategies of Explanation and Counteraction, „Russian Education and Society" 2008, t. 50, $\mathrm{nr} 11_{1}$

Izdebska J. (red.), Dziecko w rodzinie i środowisku rówieśniczym. Wybrane zagadnienia i źródła z pedagogiki społecznej, Wydawnictwo Trans Humana, Białystok 2003.

Kawula S., Pedagogika społeczna. Dzisiaj i jutro, Wydawnictwo Edukacyjne AKAPIT, 2012

Kawula S., Brągiel J., Janke A., Pedagogika rodziny, Wydawnictwo Adam Marszałek, Toruń 2005

Kesmodel U., Kesmodel P.S., Larsen A., Secher N. J., Use of alcohol and illicit drugs among pregnant Danish women, 1998 Scand, „Journal of Public Health” 2003 , t. 31

Klecka M., Janas-Kozik M., Krupka-Matuszczyk I., Rozwój diagnostyki poalkoholowego spektrum zaburzeń rozwojowych - przeglad narzędzi diagnostycznych, „Psychiatria i Psychologia Kliniczna” 2010, 10 (4)

Loon L., Ven M., Doesum K., Witteman C., Hosman, C. The Relation Between Parental Mental Illness and Adolescent Mental Health: The Role of Family Factors, „Journal of Child \& Family Studies” 2014, t. 23. z. 7

Mangueira O. Sde, Lopes M.V., Dysfunctional family in the context of alcoholism: conceptanalysis, „Revista Brasileira De Enfermagem” 2014, t. 67, nr $1_{\Lambda}$

Mantymaa M., Puura K., Luoma I., Latva R., Salmelin R. K., Tamminen T., Predicting Internalizing and Externalizing Problems at Five Years by Child and Parental Factors in Infancy and Toddlerhood, „Child Psychiatry and Human Development" 2012, t. 43, nr 2 
Martínez-Lanz P., González-González A., Betancourt Ocampo D., Domestic Violence and Alcohol and Illegal Drugs Consumption in Mexican Youth, „Journal of Health Science” 2014, t. 2

Mazur J., Przemoc w rodzinie. Teoria i rzeczywistość, Wydawnictwo Akademickie Żak, Warszawa 2002

Narkauskaitè L., Krupskienè A., Smurtas - visuomenès sveikatos problema. Smurto samprata, [w:] Smurto paplitimas ir jo prevencija Lietuvoje, Higienos institutas, World Health Organization, University of St. Andrews, Vilnius 2011

Nowak J. M., Żuryń A., Grzanka A., Kotynina - metabolizm, zastosowanie jako biomarker $i$ wplyw na organizm człowieka, „Postępy Higieny i Medycyny Doświadczalne" (on-line), 2012, nr 66.

Nowak B. M., Rodzina w kryzysie. Studium resocjalizacyjne, PWN, Warszawa 2011 Olubiński A., Wspótpraca rodziny i szkoły jako funkcja życia społecznego, w: Płaszczyzny wspótpracy szkoły ze środowiskiem lokalnym, red. L. Hurło, Wydawnictwo Magnus, Łódź 2011.

Ornoy A., Ergaz Z., Alcohol Abuse in Pregnant Women: Effects on the Fetus and Newborn, Mode of Action and Maternal Treatment, „International Journal of Environmental Research and Public Health" 2010 Feb; 7(2).

Urban B., Zaburzenia $w$ zachowaniu i niedostosowanie społeczne $w$ świetle współczesnych wyników badań, w: B. Urban, J. M. Stanik red., Resocjalizacja, t, 1,Warszawa 2008

Państwowa Agencja Rozwiązywania Problemów Alkoholowych, Narodowy Program Profilaktyki i Rozwiazywania Problemów Alkoholowych na lata 2006-2010, Warszawa

Pilch T., Miliard dzieci bez szczęścia, „Chowanna” 2010,1 (34)

Przybysz-Zaremba M., Uwarunkowania zachowań agresywnych i/lub przemocowych wystepujacych w rodzinie - wybrane konteksty. Społeczno-demograficzny model agresora - w świetle badań własnych, w: Społeczno-ekonomiczne uwarunkowania rozwoju rodziny, red. K. Szczepańska-Woszczyna, M. Hronec, Dąbrowa Górnicza 2014

Przybysz-Zaremba M., Wokół wybranych dysfunkcji rodziny jako uwarunkowań niedostosowania społecznego dzieci i młodzieży - implikacje i działania, w: S. Neslusanova, I. Emmerova, E. Jarosz red., Socialni pedagogika ve sluzbe cloveku a spolecnosti, Institut Mezioborowych Studii, Brno 2014.

Przybysz-Zaremba M., Problem nadużywania alkoholu jako determinant motywacji do podejmowania przez kobiety aktywności edukacyjno-zawodowej, w: Rodzina. Przeobrażenia, problemy, pomoc, red. I. M. Kijowska, M. Przybysz-Zaremba, PWSZ w Elblągu, Elbląg 2013 
Sadauskas J., Katkonienè A., Przybysz-Zaremba M., Przemoc w rodzinie wobec kobiet - na przykładzie Litwy - tekst złożono do druku

Salmon J., Fetal alcohol spectrum disorder: New Zealand birth mothers' experiences, „Canadian Journal of Clinical Pharmacology” 2008, nr 15

Smurtas priě̌ moteris, Europos tyrimas „Europos Sąjungos pagrindinių teisių agentūros ataskaita", 2014

Smurto prieš moteris šeimoje analizè ir smurto šeimoje auku būklès ịvertinimas: tyrimo ataskaita, BGI Consulting, 2008

Szychta W., Skoczylas M., Laudański T., Spożywanie alkoholu i palenie tytoniu przez kobiety $w$ ciąży - przegląd badań, „Perinatologia, Neonatologia i Ginekologia” 2008, t. 1, z. 4

Winiarski M., Rodzina - szkoła-środowisko lokalne. Problemy edukacji środowiskowej, Warszawa 2000

Yochum C., Doherty-Lyon S., Hoffman C., Hossain M. M., Zelikoff J. T., Richardson J. R., Prenatal cigarette smoke exposure causes hyperactivity and aggressive behavior: role of altered catecholamines and BDNF, ,Experimental Neurology” 2014, t. 254, nr 4

Zimbardo P. G., Gerrig R. J., Psychologia i życie. Wydawnictwo Naukowe PWN, Warszawa 2011

Netografia:

http://statystyka.policja.pl/st/wybrane-statystyki/przemoc-w-rodzinie/50863, Przemoc-w-rodzinie.html [dostęp. 18.08.2015]

www.szkolnictwo.pl

Dokumenty:

GUS, Bezrobocie rejestrowane, I kwartat 2015 r., Warszawa 2015

Dz. U. z 2010 r., nr 125 poz. 842

Dz. U. Nr 88, poz. 553, z późn. zm.)

\section{Malgorzata Przybysz-Zaremba: Dimorphic dimension of domestic aggression and violence conditioning - selected aspects and explorations review}

The text considers domestic aggression and violence conditioning. The analysis of agents and factors as the sources of domestic aggression and violence was of dimorphic character. Two fields were submitted to the analysis and penetration: 
pre-natal period, that is so called 'arising aggression and violence' and the field of the factors within the family-domestic surrounding of an individual. Due to the multiplicity and variety of the factors residing in these fields, there were some relations to agents of commonly destructive (pathological) character, i.e. alcohol abuse as well as to agents not bearing the traits of pathology, i.e. unemployment. Multiply quoted explorations indicate that domestic aggression and violence are rooted in the integrated macro- and micro-social aspects, at times creating a series of pejorative factors triggering domestic aggression and violence. Analysing the conditioning of aggressive and violent behaviours, some selected implications for an individual's development and functioning, mainly children, were also signalled.

Key words: aggression, violence, family, individual. 